\title{
The Effect of Fluoride and Other Ions on Algae and Fish of Coastal Water of Mediterranean Sea, Egypt
}

\author{
${ }^{1}$ M.S. Masoud, ${ }^{2}$ W.M. El-Sarraf, ${ }^{1}$ A. A. Harfoush and ${ }^{2}$ GH. F. El-Said \\ ${ }^{1}$ Chemistry Department, Faculty of Science, Alexandria University, Alexandria, Egypt \\ ${ }^{2}$ National Institute of Oceanography and Fisheries, Alexandria, Egypt
}

\begin{abstract}
Sea grass, marine algae and fish samples were collected from the Egyptian coast of Mediterranean Sea during September 2000 and March 2001. The contents of fluoride and some interfering ions (calcium, magnesium, sulphate, phosphorus and some heavy metals) ions and their concentration factors were determined in the dried samples. Fluoride contents in macrophytes, algae, muscle of fish samples were ranged between 29.79 and $34.30 \mathrm{mg} \mathrm{g}^{-1}, 19.17$ and $53.70 \mathrm{mg} \mathrm{g}^{-1}$ and 1.875 and $3.379 \mu \mathrm{g} \mathrm{g}^{-1}$, respectively. Calcium contents for sea grass, algae and fish samples were varied between 21.82 and 45.30, 45.63 and 325.37 and 18.04 and $93.00 \mathrm{mg} \mathrm{g}^{-1}$, respectively. Magnesium contents were fluctuated between 3.62 and 28.96, 1.21 and 15.70 and 45.58 and 107.84 $\mathrm{mg} \mathrm{g}^{-1}$, respectively. Sulphate contents ranged between 69.78 and 140.00 and 17.22 and $117.22,54.68$ and $185.19 \mathrm{mg} \mathrm{g}^{-1}$, respectively. Phosphorus contents were varied from 0.24 to $0.74,0.198$ to 1.854 and 3.205 to $5.477 \mathrm{mg} \mathrm{g}^{-1}$, respectively. Fluoride analysis indicated that there is no risk for human consumption of the muscles of fish samples collected from the Egyptian coast of Mediterranean Sea. The data were exposed to some statistical analyses to study the effect of fluoride and the interfering ions on the behavior of sea grass, marine algae and fish species.
\end{abstract}

Key words: Effect of fluoride, interfering ions, sea grass, marine algae, environmental chemistry

\section{INTRODUCTION}

Fluoride is present in several tropical plants as mono-fluorinated carbon compounds. The toxic principle of Dichapetalum cymosum (a poisonous South African plant "gifblaar") is fluoroacetate, which has been isolated from two Australian plants, Acacia georginae and Gastrolobium grandiflorum. Long-chain fluoro carboxylic acids have also been identified in few other Dichapetalum species ${ }^{[1]}$. The highest fluoride concentration caused 25-30\% growth rate inhibition of a diatom, a dinoflagellate and a haptophyt, other diatoms and species from other classes of algae were virtually unaffected. It is hypothesized that the unexpected lack of toxicity from fluoride ion may be due to the formation of innocuous complexes with one or more ions of seawater. The ecological inference is drawn that fluoride pollution may be readily tolerated by some marine phytoplankton under nutrient-sufficient conditions $^{[2]}$.

Fluoride complexation attenuated aluminum toxicity to Juvenile Salmon (Salmo salar) and the accumulation of it in gill tissues. Total red and white blood cell dropped consistently as fluoride in the water was increased from 5 to 300 ppm in adult Rana pipiens showing its toxicity ${ }^{[3]}$.

Ninety-six-hours $\mathrm{LC}_{50} \mathrm{~s}$ for fresh water fish range from $51 \mathrm{mg} \mathrm{L}^{-1}$ fluoride (rainbow trout, Oncorhynchus mykiss) to $460 \mathrm{mg} \mathrm{L}^{-1}$ (three spine stickleback, Gasterosteus aculeatus). All of acute toxicity tests on marine fish gave results greater than $100 \mathrm{mg} \mathrm{L}^{-1}$. Inorganic fluoride toxicity to fresh water fish appears to be negatively correlated with water hardness $\left(\mathrm{CaCO}_{3}\right)$ and positively correlated with temperature. The symptoms of acute fluoride intoxication include lethargy, violent and erratic movement and death ${ }^{[4]}$.

Behavioral experiments on adult Pacific Salmon (Oncorhynchus sp.) in Soft Water Rivers indicated the changes in water chemistry resulting from an increase in the fluoride concentration to $0.5 \mathrm{mg}$. These can adversely affect migration and migrating salmon and are extremely sensitive to changes in water chemistry of their river of origin ${ }^{[4]}$.

While 1-2 mg F/day are recommended for caries prevention, the daily consumption of 20-80 mg fluoride in humans led to calcification of muscles and ligaments. After several years of intake, symptoms of osteosclerosis such as superaclification and thereby reduction of bone marrow followed, leading to decreased production of erythrocytes ${ }^{[5]}$.

The aim of the present study is to study the distribution and the effect of fluoride on some bottom marine algae and fish samples collected from the Egyptian coast of Mediterranean Sea.

\section{MATERIALS AND METHODS}

Locations and collection of samples: Fix perpendicular stations to the Mediterranean shore belt were selected to represent different parts of Egyptian

Corresponding Author: M. S. Masoud, Chemistry Department, Faculty of Science, Alexandria University, Alexandria, Egypt 
coast, Fig. 1. They extend between Sidi Barrani in the west to Damietta in the east of the Egyptian coast for a distance of about $500 \mathrm{Km}$ long and $3 \mathrm{Km}$ from the shore line. Random bottom fauna samples were collected using trawl net of research vessel El Yarmook from Damietta, Abu Qir, El Alamein, Ras El Hikmah, Marsa Matruh and Sidi Barrani at depths of about, (2491), (30-50), (37-41), (55-67), (43-67) and (42-66) m, respectively. However, the algal and fish samples were selected for analysis. These stations are given as follows:

Damietta: It is in the eastern side of Nile Delta region. It receives large amounts of drainage water (agricultural, sewage and industrial effluents) coming from both Damietta and Lake El Manzalah.

Abu Qir: It is in front of Abu Qir bay that receives large amounts of three types of waters; Rosetta mouth of the river Nile, Lake Edku via Boughaz El Maadiya and Tapia pumping station. These waters enter the coastal area causing change in its chemical composition and contain high components of discharged water from industrial wastes (fertilizer industry, textile manufacturing, paper industry, chemical and soap, salt factories and food processing), fresh water, domestic, fertilizers and agricultural wastes.

El Alamein, Ras El Hikmah, Marsa Matruh and Sidi Barrani: These are located in the western side of Alexandria.

Samples classification: The algal and fish samples were identified to their possible species and genus, Tables 1 and 2).

Samples preservation: They were washed by tap water followed by distilled water and then stored in polyethylene bags. They were frozen under $-20^{\circ} \mathrm{C}$ and dried in an oven at $70^{\circ} \mathrm{C}$ to a constant weight then crushed to a fine powder.

Samples preparation: They were exposed to many types of digestions according to its purpose of analysis.

* A mixture of nitric, hydrochloric and hydrofluoric acids in Teflon cubs digested $0.5 \mathrm{gm}$ of the dried fine powdered samples of algae. The digested solutions were used for the analyses of heavy metals, phosphorus, sulfur, calcium and magnesium contents.

* $\quad 1.0 \mathrm{gm}$ of the dried fine powdered fish samples were digested using a concentrated nitric acid in Teflon cubs at room temperature and used for fluoride, sulphur, phosphorus, calcium magnesium and heavy metals analyses.

* $\quad 0.1$ gm of the fine powdered algal samples was digested using a concentrated perchloric acid in Teflon cubs at room temperature and used for the fluoride analysis. Table 3, represents a comparative study for the analysis of fluoride content in different digestive media containing the same weight of NaF. It seems that $\mathrm{HNO}_{3}$ and $\mathrm{HClO}_{4}$ acids are the suitable media for fluoride analysis. The low fluoride content obtained from the digestion of $\mathrm{NaF}$ with $\mathrm{HNO}_{3}-\mathrm{H}_{2} \mathrm{O}_{2}$ and its fusion with sodium bismuthate and sodium hydrogen sulphate, may be attributed to the liberation of volatile HF or probably due to the oxidation of the alizarin reagent.

Calcium and magnesium concentrations were determined by EDTA titration in presence of murexide and Eriochrome black $\mathrm{T}$ indicator ${ }^{[[]]}$.

Sulphate concentration was estimated by turbidimetric method $^{[6]}$, using Perkin Elmer Lambda/UV/visible single beam spectrophotometer at $\lambda=420 \mathrm{~nm}$.

Fluoride ion concentration was determined following the procedure of zirconium alizarin red $\mathrm{S}^{[7]}$.

Phosphorus content was evaluated based on the reaction with an acidified molybdate reagent to yield phosphomolybdate complex, which then reduced to a coloured blue compound ${ }^{[8]}$.

Heavy metals contents in the samples were determined using Perkin-Elmer 2380, atomic absorption spectrophotometer.

The data of the different parameters are used to calculate the correlation coefficient ( $r$ ), using the following equation ${ }^{[9]}$.

$$
r=\frac{\sum x y-\frac{\sum x \sum y}{n}}{\sqrt{\left[\sum x^{2}-\frac{\left(\sum x\right)^{2}}{n}\right]\left[\left(\sum y^{2}\right)-\frac{\left(\sum y\right)^{2}}{n}\right]}}
$$

Where: $\mathrm{x}, \mathrm{y}$ are two different parameters. $\mathrm{n}$ : is the number of samples.

\section{RESULTS AND DISCUSSION}

Calcium: Calcium content in Posidonia oceanica (Sea grass) is ranged between 21.82 and $45.30 \mathrm{mg} \mathrm{g}^{-1}$ in $\mathrm{Abu}$ Qir and El Alamein, respectively, Table 3. This is probably due to precipitation of carbonates on the leaves during photosynthesis process ${ }^{[10]}$. The results are in harmony with the macrophytes of Lake Edku. However, the calcium content was ranged between 18.1 and $34.7 \mathrm{mg} \mathrm{g}^{-1}$ for Ceratophyllum demersum and Eiphyteson C. demersum, respectively ${ }^{[11]}$, higher than in Lake Mezzola (Northern Italy) ${ }^{[12]}$. Calcium concentration in the algal species (green, red and brown) is varied between 45.63 and $325.37 \mathrm{mg} \mathrm{g}^{-1}$ for Asparagoposis sp. (red algae) and Amphiroa sp. (red algae) collected from El Alamein and Ras El Hikmah, respectively, Table 3 . The change in this content in the present work may refer to the different requirements of algal species ${ }^{[10]}$. Calcium concentration factor is varied between 78.04 and $1608.1 \mathrm{mg} \mathrm{g}^{-1}$ between Posidonia 
oceanica and Amphiroa sp. from El Alamein during September 2000 and March 2001, , Table 4, respectively. Calcium seems to be variable along all the algal species possibly due to the specific character for each species of algae ${ }^{[10]}$. The determined data, Table 3 , reflect that Penicillus capitatus (green algae) and Amphiroa sp. (red algae) are calcareous algae of high calcium content. However, the red algae are aragonitic but contain some magnesium calcite ${ }^{[14]}$. The present investigation gives higher values in the algal species of the western studied area (El Alamein, Ras El Hikmah and Sidi Barrani) than in the eastern ones (Abu Qir), Table 3. This may refer to the higher existence in sediments and column water. Codium bursa and Sargassum sp. contain higher contents than Codium tomentosum and Sargassum hornschuchii collected from Alexandria coast ${ }^{[13]}$. This may confirm the higher accumulation in the western region of the coastal water of Mediterranean Sea Egypt.

Fish species live on the bottom of the sea are of lower calcium content, than the pelagic, Fig. 2 and ranged between 18.04 and $93.00 \mathrm{mg} \mathrm{g}^{-1}$ for Bothus podas and Hippocampus hippocampus collected from El Alamein and Damietta during 2001, respectively. Bothus podas, Arisoma balearicum and Synodus saurus show contents of 18.04, 39.21 and $39.36 \mathrm{mg} \mathrm{g}^{-1}$ at El Alamein, Marsa Matruh and Sidi Barrani, respectively. However, the mean calcium contents of seawater of El Alamein and Marsa Matruh sectors are of lower values than that of Damietta and Sidi Barrani. The whole body of Hippocampus hippocampus caught from Damietta sector shows the highest calcium content $\left(93.00 \mathrm{mg} \mathrm{g}^{-1}\right.$ ) due to the presence of phosphate apatites in bone structure $^{[15]}$. The high content in Boops boops, Lepidotrigla cavillone and Stephanolepis diaspros is not only affected by its value in both sediment and water but also by feeding ${ }^{[16]}$. However, fish can absorb calcium and magnesium directly from water and food $^{[17]}$. The calcium concentration factor is ranged between 93.13 and 257.95 for Bothus podas and Lepidotrigla cavillone collected from El Alamein and Sidi Barrani, respectively. Hippocampus hippocampus shows the highest concentration factor (282.50).

Magnesium: Magnesium content and concentration factor for Posidonia oceanica (sea grass) are ranged between 3.62 and $28.96 \mathrm{mg} \mathrm{g}^{-1}$ and 4.65 and 31.11 in Abu Qir and El Alamein, respectively, Tables 3 and 4. The high magnesium accumulation in El Alamein is probably due to its content in water and sediment and the different chlorophyll value in varies species ${ }^{[11]}$. The magnesium concentration in macrophytes from Lake Mezzola was 2.372, 3.413 and $3.083 \mathrm{mg} \mathrm{g}^{-1}$ for Potamogeton crispus, Callitriche stagnatis and Ranunculus sp., respectively ${ }^{[12]}$, lower than the present work. Magnesium content is varied from 1.21 to 15.70 $\mathrm{mg} \mathrm{g}^{-1}$ for Penicillus capitatus and Codium bursa from Sidi Barrani and Abu Qir, respectively, Table 3.

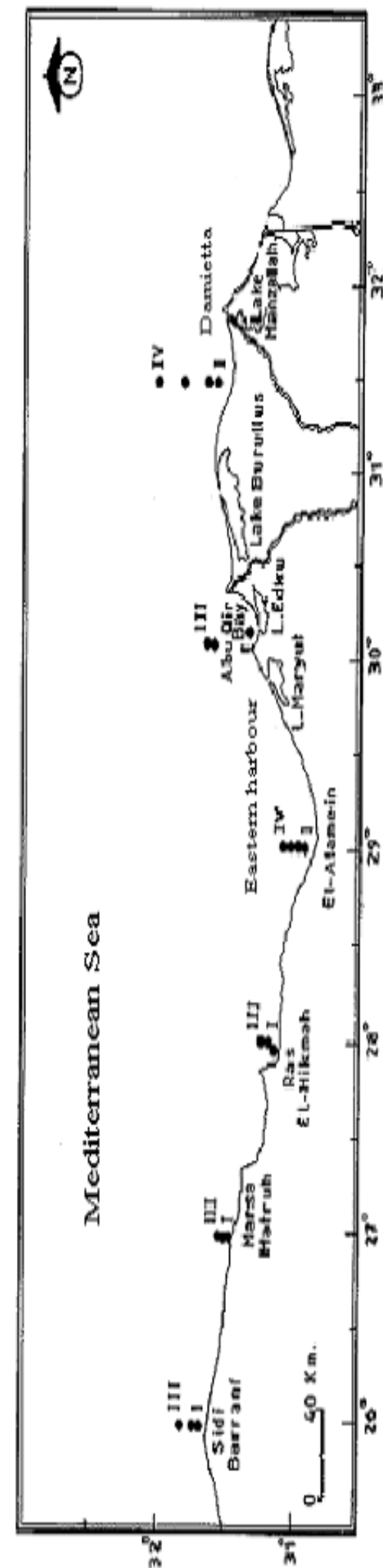

Fig. 1: Sampling locations of the Egyptian coast of Mediterranean Sea during 2000-2001

Its concentration factor is fluctuated between 1.8 and 23.71 for Codium bursa and Sargassum sp. from Sidi Barrani, respectively. Codium bursa (green algae) and 


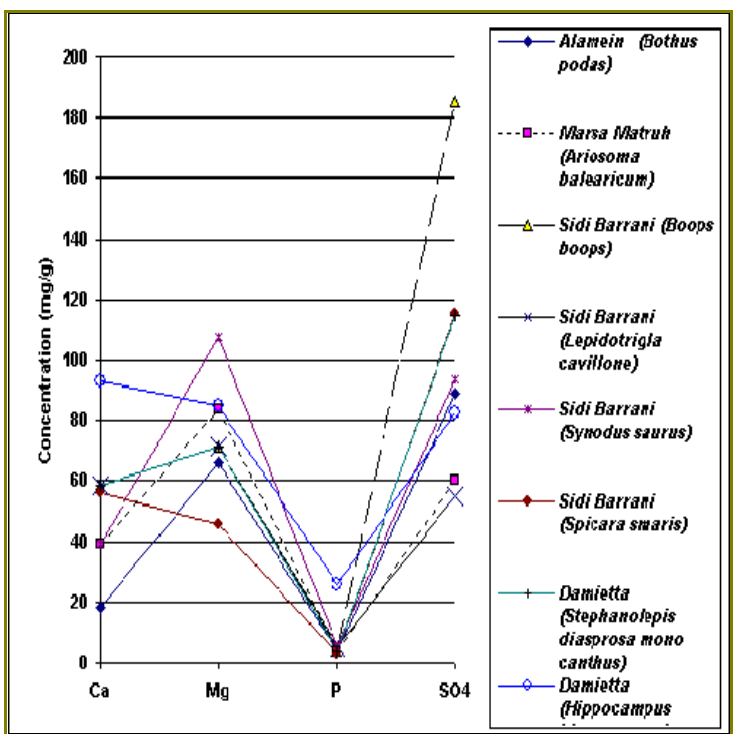

Fig. 2: Distribution of some parameters content $(\mathrm{mg} / \mathrm{g})$ in different fish samples collected from the Egyptian coast of Mediterranean Sea during March 2001

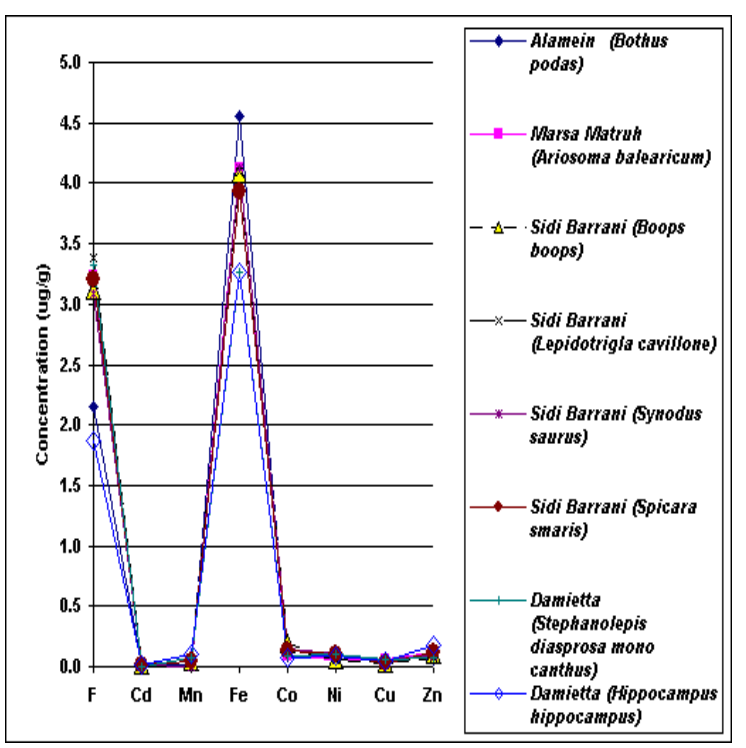

Fig. 3: Distribution of some parameters content $(\mu / g)$ in different fish samples collected from the Egyptian coast of Mediterranean Sea during March 2001

sargassum sp. (brown algae) showed higher magnesium contents, probably accompanied with the periodic fluctuations in the ambient environment and with the changes in the organisms' metabolism ${ }^{[14]}$. The present study indicates that the algal magnesium content is of lower values than for the beaches of Alexandria ${ }^{[13]}$, may be attributed to the changes in environment and the difference in the organisms metabolism ${ }^{[14]}$.

The magnesium content, Fig. 2 and concentration factor of Spicara smaris and Synodus saurus are ranged between 45.58 and $107.84 \mathrm{mg} \mathrm{g}^{-1}$ and 68.97 and 163.17
Table 1: Classification of the Sea grass and algae (Phylum: Thallophyta) collected from the coast of Mediterranean Sea during. September 2000 and March 2001

\begin{tabular}{|c|c|c|c|}
\hline $\begin{array}{l}\text { Macrophyta } \\
\text { and algae }\end{array}$ & Species & Location & $\begin{array}{l}\text { Date of } \\
\text { collection }\end{array}$ \\
\hline Sea grass & $\begin{array}{l}\text { Posidonia } \\
\text { oceanica }\end{array}$ & $\begin{array}{l}\text { El Alamein } \\
\text { Abu Qir } \\
\text { El Alamein }\end{array}$ & $\begin{array}{l}2000 \\
2001 \\
2001\end{array}$ \\
\hline & $\begin{array}{l}\text { Penicillus } \\
\text { capitatus }\end{array}$ & $\begin{array}{l}\text { El Alamein } \\
\text { El Alamein } \\
\text { Abu Qir } \\
\text { Marsa Matruh } \\
\text { Sidi Barrani }\end{array}$ & $\begin{array}{l}2000 \\
2001 \\
2001 \\
2001 \\
2001\end{array}$ \\
\hline $\begin{array}{l}\text { Chlorophyta } \\
\text { (Green } \\
\text { algae) }\end{array}$ & Codium bursa & $\begin{array}{l}\text { Abu Qir } \\
\text { El Alamein } \\
\text { Ras El }\end{array}$ & $\begin{array}{l}2001 \\
2001\end{array}$ \\
\hline & Ulva lactuca & $\begin{array}{l}\text { Hikmah } \\
\text { Marsa Matruh } \\
\text { Sidi Barrani } \\
\text { Sidi Barrani }\end{array}$ & $\begin{array}{l}2001 \\
2001 \\
2001 \\
2001\end{array}$ \\
\hline & Amphiroa $s p$. & El Alamein & 2001 \\
\hline $\begin{array}{l}\text { Rhodophyta } \\
\text { (Red algae) }\end{array}$ & Asparagoposis sp. & $\begin{array}{l}\text { Abu Qir } \\
\text { Ras El } \\
\text { Hikmah } \\
\text { Sidi Barrani } \\
\text { El Alamein }\end{array}$ & $\begin{array}{l}2001 \\
2001 \\
2001 \\
2000\end{array}$ \\
\hline $\begin{array}{l}\text { Phaeophyta } \\
\text { (Brown } \\
\text { algae) }\end{array}$ & Sargassum sp. & $\begin{array}{l}\text { El Alamein } \\
\text { Ras El } \\
\text { Hikmah } \\
\text { Marsa Matruh } \\
\text { Sidi Barrani }\end{array}$ & $\begin{array}{l}2000 \\
2001 \\
2001 \\
2001\end{array}$ \\
\hline
\end{tabular}

at Sidi Barrani sector, respectively, may be related to the type of feeding of the two species ${ }^{[19]}$. Generally, the present study shows that the fish which live on the bottom of the sea water contain higher magnesium content than the pelagic ones. However, Spricara smaris contains lower magnesium content than Synodus saurus. Its content in the whole body belongs to Hippocampus species is of $84.92 \mathrm{mg} \mathrm{g}^{-1}$, Fig. 2. Magnesium contents in the present study are of higher values than that recorded ${ }^{[16]}$. This may be attributed to the analysis of the dry weight samples and the high magnesium content in the marine fish samples.

Sulphate: Sulphate content and its concentration factors are ranged between 69.78 and $140.00 \mathrm{mg} \mathrm{g}^{-1}$ and 23.2 and 174.5 in Posidonia oceanica collected from El Alamein and Abu Qir, respectively, Tables 3 and 4. Sulphate concentration is ranged between 17.22 and $117.22 \mathrm{mg} \mathrm{g}^{-1}$ in Penicillus capitatus and Sargassum sp. from Marsa Matruh and Ras El Hikmah, respectively, Table 3. Most algae can supply their sulphur reqiuement by reducing sulphate, or other sources of sulphur such as: methionine, cysteine, homocysteine, sulpholipid and sulphite ${ }^{[10]}$. Sulphur is considered as an important component, while a large part of it in most algae is incorporated into protein, sulpholipids, sulphite, sulphonium compounds, sulphate, sulphuric acid, ...etc ${ }^{[10]}$. Many studies on algae indicated a special requirement for sulphur in cell 
Am. J. Environ. Sci., 2 (2): 49-59, 2006

Table 2: The family of fish species collected from the coastal water of the Mediterranean Sea of Egypt during March 2001 and their type of

\begin{tabular}{|c|c|c|c|}
\hline Family & Fish species & Existence $^{(36)}$ & Feeding $^{(36)}$ \\
\hline Bothidae & Bothus podas & Live on the bottom & Small mollusca and crustaceans \\
\hline Congridae & Ariosoma balearicum & Live on the bottom & Fish and crustaceans \\
\hline Sparidae & Boops boops & $\begin{array}{l}\text { Live in schools either in wide } \\
\text { waters or close to the bottom } \\
\text { (pelagic) }\end{array}$ & $\begin{array}{l}\text { Small crustaceans, mollusca, } \\
\text { seaweeds, algae and sponges }\end{array}$ \\
\hline Triglidae & Lepidotrigla cavillone & $\begin{array}{l}\text { Live on the bottom (bottom } \\
\text { dwelling fishes) }\end{array}$ & $\begin{array}{l}\text { Shrimp, swimming crabs, small } \\
\text { crustaceans and small squids }\end{array}$ \\
\hline Synodontidae & Synodus saurus & Live on the bottom & Fish and crustaceans \\
\hline Centracanthidae & Spicara smaris & $\begin{array}{l}\text { Live between the surface and } \\
\text { bottom (pelagic) }\end{array}$ & $\begin{array}{l}\text { Crustaceans, algae, copepods and } \\
\text { small benthic invertebrate }\end{array}$ \\
\hline Monacanthidae & Stephanolepis diaspros mono canthus & Live over rocky bottom $(10-100 \mathrm{~m})$ & Mollusca and crustaceans \\
\hline Syngnathidae & Hippocampus hippocampus & $\begin{array}{l}\text { Live in shallow inshore water } \\
\text { among algae }\end{array}$ & Phytoplankton \\
\hline
\end{tabular}

Table 3: Comparative studies for the analysis of fluoride content of $\mathrm{NaF}$ in the presence of different digestive media

\begin{tabular}{llllllllll}
\hline Digestive Media & Fusion & $\mathrm{NaHSO}_{4}$ & $\mathrm{NaBiO}_{3}$ & $\mathrm{Na}_{2} \mathrm{CO}_{3}$ & $\begin{array}{l}\mathrm{HNO}_{3} \\
\text { room Temp. }\end{array}$ & $\begin{array}{l}\mathrm{HNO}_{3} \\
\text { Warming }\end{array}$ & $\begin{array}{l}\mathrm{HNO}_{3}+ \\
\mathrm{H}_{2} \mathrm{O}_{2}\end{array}$ & $\begin{array}{l}\mathrm{HNO}_{3}+ \\
\mathrm{HClO}_{4}\end{array}$ & $\begin{array}{l}\mathrm{NaOH}^{2} \\
\mathrm{HClO}_{4}\end{array}$ \\
\hline $\mathrm{F} \%\left(\mathrm{~F}_{\text {exp }} / \mathrm{F}_{\text {calc }}\right)$ & 14.63 & 27.31 & 90.33 & 99.22 & 99.22 & 64.40 & 96.89 & 95.80 & 96.9 \\
\hline
\end{tabular}

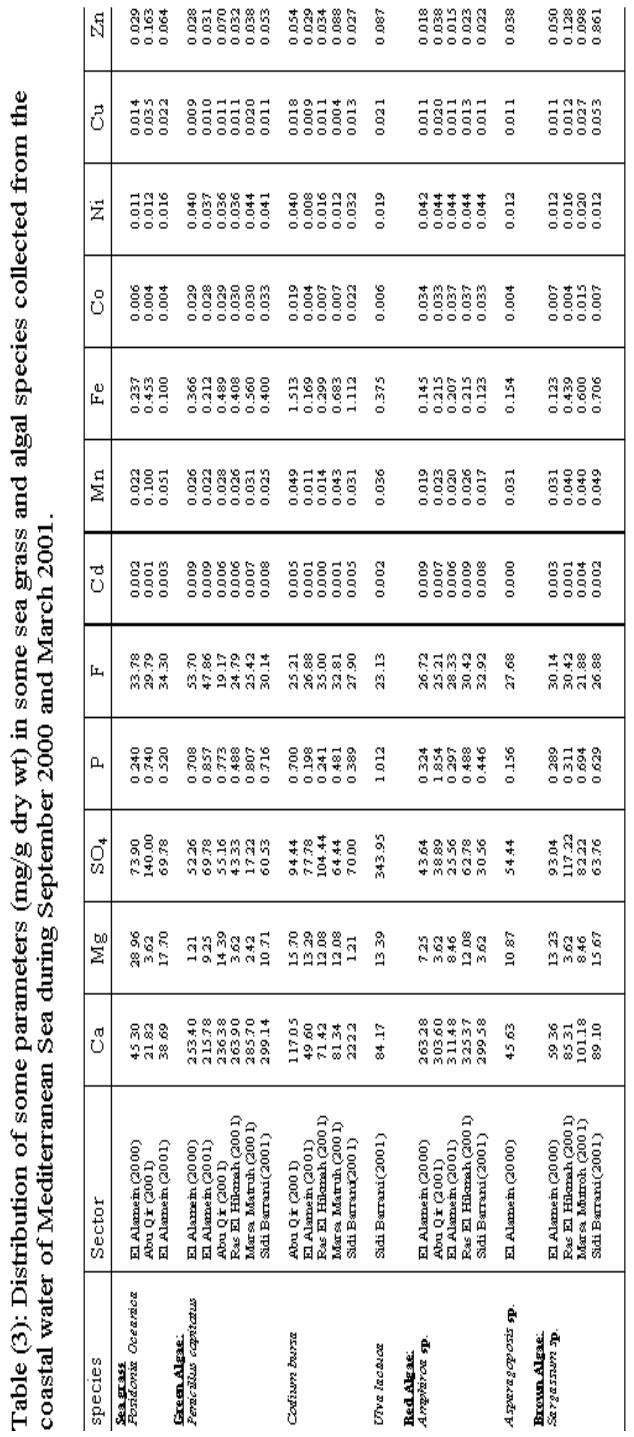

division $^{[10]}$. Its concentration factor is ranged between 13.7 and 307.8 for Amphiroa sp. and Sargassum sp. from El Alamein and Ras El Hikmah, respectively, Table 4. Generally, the present data indicated that Penicillus capitatus and Amphiroa sp. contain lower sulphate content than the present species, Table 3.

The sulphate content, Fig. 2 and concentration factor in the muscle of the fish samples are ranged between 54.68 and $185.19 \mathrm{mg} \mathrm{g}^{-1}$ and 125.90 and 426.41 in Lepidotrigla cavillone and Boops boops species collected from Sidi Barrani sector and affected by the feeding of each species and their existence ${ }^{[16]}$. However, Boops boops (pelagic) shows the highest value of $185.19 \mathrm{mg} \mathrm{g}^{-1}$ and Lepidotrigla cavillone (lives near the bottom) is of low content $\left(54.68 \mathrm{mg} \mathrm{g}^{-1}\right)$.

Phosphorus: Phosphorus content in Posidonia oceanica is ranged between 0.24 and $0.74 \mathrm{mg} \mathrm{g}^{-1}$ in El Alamine and Abu Qir, respectively, Table 3. The high content in Abu Qir sector may be accompanied with its concentration in sediment and water column and the discharged water coming from El Umum drain and Rosetta branch. Its concentration in the algal species is varied from 0.198 and $1.854 \mathrm{mg} \mathrm{g}^{-1}$ for Codium bursa and Amphiroa sp. in El Alamein and Abu Qir, respectively, Table 3. The algal species in Abu Qir are of high phosphorus contents, Table 3 and may be attributed to the metabolic reactions ${ }^{[10]}$, environmental conditions $^{[10]}$ and seasonal variation ${ }^{[10]}$.

Nearly half of the phosphorus in fish is located in bone and scales ${ }^{[19]}$. Fish are often long lived and thus can serve as reservoirs of nutrients ${ }^{[19]}$. Phosphorus contents in the muscles of fish samples are ranged between 3.205 and $5.477 \mathrm{mg} \mathrm{g}^{-1}$ for Spicara smaris and Synodus saurus collected from Sidi Barrani sector, respectively, Fig. 2. The phosphorus content of the 
whole body of Hippocampus hippocampus collected from Damietta is of $25.546 \mathrm{mg} \mathrm{g}^{-1}$ to reflect its high content in the bone skeleton ${ }^{[19]}$. The phosphorus contents of the whole body of Cottus bairdi and Lota lota were $26.8 \pm 2.4$ and $19.1 \pm 2.4 \mathrm{mg} \mathrm{g}^{-1}$ collected from Bark Bay, Wisconsin, respectively ${ }^{[19]}$. However, the content is not only dependent on trophic level, location and length but also depends on both growth rate indices and fineness ${ }^{[19]}$.

Fluoride: Its concentration is varied from 29.79 to $34.30 \mathrm{mg} \mathrm{g}^{-1}$ for Posidonia oceanica collected from Abu Qir and El Alamein, respectively, Table 3 and Fluoride concentration factor is varied from 6081.6 to 9129.7 during March 2001 and September 2000, respectively. In algal species it is flactuated between 19.17 and $53.70 \mathrm{mg} \mathrm{g}^{-1}$ in Penicillus capitatus from Abu Qir and El Alamein, respectively, Table 3 and its concentration factor is ranged between 4065.0 and 12935.1 in Ulva lactuca and Penicillus capitatus from Sidi Barrani and El Alamein in Spring 2001, respectively, Table 4. However, its accumulation not only shows variable contents along all the studied species but also in the same species collected from different sectors. Furthermore, the seasonal variation appears to contribute in the fluctuation. Fluoride has possible beneficial effect on algal development ${ }^{[20]}$. Previous studies reported that the respiration rate was affected by fluoride accumulation and either inhibition or stimulation may depend on its concentration and other factors such as the species and age of plant and the time of exposure ${ }^{[4]}$.

The fluoride content in the muscle of the fish species is ranged between 1.875 and $3.379 \mu \mathrm{g} \mathrm{g}^{-1}$ in Hippocampus hippocampus and Lepidotrigla cavillone in Damietta and Sidi Barrani sectors, respectively, Fig. 3. However, the fluoride content is probably attributed to the constituents of the food of nutrition ${ }^{[21]}$. The concentration factor is ranged between 0.38 and 0.87 for Bothus podas and Ariosoma balearcium in El Alamein and Marsa Matruh, respectively. However, Ariosoma balearicum is feeding on fish and crustaceans (of high fluoride content). The maximum fluoride content in seawater column, may cause its accumulation in the muscle of fish species. The fluoride content in the wet weight of the muscle tissue of Gadus morrhua and Gadus aeglifinus was 1.7 and $1.8 \mathrm{mg} \mathrm{Kg}^{-1}$ caught in the North Sea ${ }^{[21]}$. However, the increased fluoride content in the muscle tissue of the species fed on crustaceans, algae, molluscs, small fish,...etc, is due to the nutritional availability of fluoride ${ }^{[21]}$. Its content in the fish flesh is lower than the permissible limit in USA (100 $\mathrm{mg} \mathrm{Kg}^{-1}$ ), probably due to its accumulation to skin, scales, bone skeleton, gills, ...etc ${ }^{[21,22]}$ and its distribution between seawater and sediment ${ }^{[23]}$.

Heavy metals: Iron concentration in Posidonia oceanica (macrophyta) is ranged from 0.100 to 0.453 $\mathrm{mg} \mathrm{g}^{-1}$ from El Alamein and Abu Qir, respectively, Table 3, may be accompanied with its content in sediment and water column. However, rooted aquatic plants can absorb metals through both their leaves and roots via the surrounding water and sediment interstitial water, respectively ${ }^{[24]}$. In the present study, Posidonia oceanic from Abu Qir shows the highest iron content, may be attributed to its existence in sediment and water column $^{[12]}$. Iron content in Posidonia oceanica agrees with the reported data in Edku, Mariut Lakes and Alexandria beaches ${ }^{[11,25]}$. Its concentration in algal species is $0.123,0.123$ and $1.513 \mathrm{mg} \mathrm{g}^{-1}$ for Amphiroa sp. Sargassum sp. and Codium bursa from Sidi Barrani, El Alamein and Abu Qir, respectively, Table 3. Green and brown algae are of higher content than red algae, Table 3, to reflect the different requirements of the various species ${ }^{[26]}$ and the environmental change ${ }^{[26]}$. Iron content in green algae seems to be higher than the recorded data except Ulva lactuca which contains lower value than the determined in Suez Canal ${ }^{[16]}$, probably due to the environmental change ${ }^{[27]}$. However, the variation of the metal content in algae from site to site is depended on the physicochemical factors such as: temperature, $\mathrm{pH}$, salinity, wave exposure, light, etc ${ }^{[16]}$.

Iron concentration is ranged between 3.26 and $4.55 \mu \mathrm{g} \mathrm{g}^{-1}$ in Hippocampus hippocampus and Bothus podas species collected from Damietta and El Alamein, respectively, Fig. 3.The iron contents in the fish samples collected from El Alamein, Marsa Matruh and Sidi Barrani record relatively higher value than that for Damietta samples, probably due to its content in their feeding ${ }^{[16]}$. The iron content of the muscle of Boops boops taken from Shanshoulla working in Alexandria coastal water was ranged from $5.633 \pm 2.424$ and $41.519 \pm 76.486 \mu \mathrm{g} \mathrm{g}^{-1}$ in August and March, respectively. The high content determined in all organs was in spawning month, March ${ }^{[27]}$. However, the fish muscles are of lower values than reported ${ }^{[27]}$.

The manganese concentration of Posidonia oceanica is varied between 0.022 and $0.100 \mathrm{mg} \mathrm{g}^{-1}$ for El Alamein and Abu Qir, respectively, Table 3. The high content may be accompanied with its existence in sediment and water ${ }^{[26]}$. Its content in algal species is ranged between 0.011 and $0.049 \mathrm{mg} \mathrm{g}^{-1}$, respectively, Table 3. Codium bursa is of variable contents along the different sectors, Table 3. Brown algae show higher concentrations than green and red, Table 3. Manganese content in the present algal species agrees with the reported data ${ }^{[25,28]}$.

The manganese content of the muscles of the fish samples is ranged between 0.000 and $0.069 \mu \mathrm{g} \mathrm{g}^{-1}$ in Synodus saurus and Stephanolepis diaspros in Sidi Barrani and Damietta sectors, respectively, Fig. 3. The relative high manganese content in the fish species may reflect its existence in food and sediment. Its relative maximum content in Hippocampus hippocampus species $\left(0.109 \mu \mathrm{g} \mathrm{g}^{-1}\right)$ may be accompanied with the 
analysis of the whole body. Generally, the determined manganese content in the muscle of the fish samples is lower than the reported data ${ }^{[29]}$. However, it was reported that ${ }^{[35]}$ its content was $4.87 \pm 0.30,7.68 \pm 1.15$ and $6.65 \pm 0.36 \mu \mathrm{g} \mathrm{g}^{-1}$ for the muscle of Chactadon jayakeri, Rastrelliger kanagurta and Pomadysis maculatum collected from the Arabian Sea, respectively ${ }^{[35]}$.

Cobalt content in Posidonia oceanica is ranged between 0.004 and $0.006 \mathrm{mg} \mathrm{g}^{-1}$ from Abu Qir and El Alamein, respectively, Table 3 , however, sea grass is lower than in Potamogeton crispus $(0.007 \pm 0.010 \mathrm{mg}$ $\mathrm{g}^{-1}$ ) collected from Lake Mezzola ${ }^{[12]}$. Its content in the algal species is fluctuated between 0.004 and $0.037 \mathrm{mg}$ $\mathrm{g}^{-1}$, Table 3. Penicillus capitatus and Amphiroa sp. show higher cobalt content than the other species, Table 3 , probably due to the change of requirement of each species $^{[10]}$. Its content in Ulva lactuca is relatively similar to that determined in Suez Canal ${ }^{[16]}$.

The deduced content in the muscle of fish samples is ranged between 0.074 and $0.187 \mu \mathrm{g} \mathrm{g}^{-1}$ determined in Hippocampus hippocampus and Boops boops, in Damietta and Sidi Barrani, respectively, Fig. 3. The relative high content of Boops boops $\left(0.187 \mathrm{mg} \mathrm{g}^{-1}\right)$, is probably due to is a pelagic fish feeding on algae and invertebrates $^{[18]}$. The total content of trace metals is higher in plankton and invertebrates ${ }^{[27]}$. The cobalt content in the muscle of Mugil seheli and Solea solea collected from Suez Canal was $0.205 \pm 0.02$ and 0.116 $\pm 0.04 \mu \mathrm{g} \mathrm{g}^{-1}$ wet wt, respectively ${ }^{[27]}$. The mean cobalt content in the muscles of Sparus auratus and Scaiena aqiulla ranged from 0.005 to 0.170 and 0.02 to $0.07 \mathrm{mg}$ $\mathrm{Kg}^{-1}$, respectively ${ }^{[27]}$.

Nickel content in Posidonia oceanica is varied from 0.011 to $0.016 \mathrm{mg} \mathrm{g}^{-1}$ from El Alamein, Table 3 . Its concentration in the algal species is ranged between 0.008 and $0.044 \mathrm{mg} \mathrm{g}^{-1}$, Table 3. Codium bursa collected from Abu Qir shows the highest content $\left(0.040 \mathrm{mg} \mathrm{g}^{-1}\right)$, probably due to its existence in sediment and water column ${ }^{[16]}$, Table 3 . The high contents in both Penicillus capitatus and Amphiroa sp. are probably attributed to the requirement of each species $^{[10]}$.

The nickel content in the fish samples is ranged between 0.052-0.103 $\mu \mathrm{g} \mathrm{g}^{-1}$, Fig. 3, lower than the reported ${ }^{[29]}$, probably due to the change in the water properties, time of collection and feeding ${ }^{[27]}$. It was reported that ${ }^{[29]}$ its content in the muscle of some marine fish samples collected from Arabian Sea was $12.12 \pm 1.59,18.28 \pm 3.67$ and $12.09 \pm 1.18 \mu \mathrm{g} \mathrm{g}^{-1}$ wet wt for Chactadon jayakeri, Rasterlliger kanagurta and Pomadysis maculatum, respectively ${ }^{[29]}$. Its content in the muscle of Mugil seheli collected from Suez Canal (Port Tawfik) was $1.098 \pm 0.58 \mu \mathrm{g} \mathrm{g}{ }^{-1}$ wet wt, respectively ${ }^{[16]}$.

The copper content in Posidonia oceanica is varied between 0.014 and $0.035 \mathrm{mg} \mathrm{g}^{-1}$ from El
Alamein and Abu Qir, respectively, Table 3 and of higher value $\left(0.035 \mathrm{mg} \mathrm{g}^{-1}\right)$ than of the macrophytes collected from Edku, Maruit lakes and Alexandria beaches ${ }^{[11,25]}$, probably accompanied with the environmental conditions ${ }^{[16]}$. The concentration in the algal species (seaweeds) is fluctuated between 0.004 and $0.053 \mathrm{mg} \mathrm{g}^{-1}$, respectively, Table 3. Furthermore, Sargassum sp. (brown algae) and Amphiroa sp.(red algae) seem to be affected by the ambient medium ${ }^{[16]}$, Table 3.

The copper contents in the fish samples are ranged between 0.034 and $0.053 \mu \mathrm{g} \mathrm{g}^{-1}$, Fig. 3. Generally, its content is lower than reported ${ }^{[27,29,30]}$. However, many factors affect its existence in the muscle of fish for example: spawning season, feeding rate, its content in water and in sediment ${ }^{[27]}$. It was reported that ${ }^{[16]}$ its content in Mugil seheli collected from Suez Canal was $1.185 \pm 0.38 \mu \mathrm{g} \mathrm{g}^{-1}$ wet $\mathrm{wt}^{[16]}$.

The zinc content in Posidonia oceanica is ranged between 0.029 and $0.163 \mathrm{mg} \mathrm{g}^{-1}$ from El Alamein and Abu Qir, respectively, Table 3. Its content in algal species is fluctuated from 0.015 to $0.861 \mathrm{mg} \mathrm{g}^{-1}$ for Amphiroa sp. and Sargassum sp. from El Alamein and Sidi Barrani, respectively, Table 3. The present data proved that its content in both green and brown algae is higher than in red. In general, machrophyte and seaweeds collected from Abu Qir sector show high zinc contents, Table 3, possibly due to the environmental conditions and growth stages ${ }^{[16,13]}$.

It is ranged between 0.055 and $0.113 \mu \mathrm{g} g$ ${ }^{-1}$ Bothus podas and spicara smaris along El Alamein and Sidi Barrani, respectively, Fig. 3. It involves many physiological mechanisms such as: growth, vision, sexual, maturity, spawning and organic functions. The increase in its content was toxic for sensitive species ${ }^{[27]}$. The present results are of lower contents than reported $^{[27,29,30]}$. Its content in the muscle of Boops boops and Sadrinellaa aurita collected from Mediterranean Sea was $10.00 \pm 4.43$ and $12.15 \mu \mathrm{g} \mathrm{g}^{-1}$ ${ }^{[27]}$. It was recorded that ${ }^{[16]}$ the zinc content in the muscle of fish of Mugil seheli and Tilapia aurata was $7.96 \pm 2.02$ and $9.91 \pm 3.05 \mu \mathrm{g} \mathrm{g}^{-1}$ wet wt, respectively. Its content in the muscle of some fish samples collected from the Arabian Sea were: $4.99 \pm 0.36,19.83 \pm 2.00$ and $7.22 \pm 0.51 \mathrm{\mu g} \mathrm{g}^{-1}$ wet wt in Chactadon jayakeri, Rastrelliger kanagurta and Pomadysis maculatum, respectively ${ }^{[29]}$.

Cadmium content in Posidonia oceanica is ranged between 0.001 and $0.003 \mathrm{mg} \mathrm{g}^{-1}$ from Abu Qir and El Alamein, respectively, Table 3. Its content in algal species is varied from 0.000 to $0.009 \mathrm{mg} \mathrm{g}^{-1}$, respectively, Table 3. Penicillus capitatus and Amphiroa sp. show high cadmium contents, possibly accompanied with the physiological variations of each species $^{[31]}$. However, in both calcareous algal species $\mathrm{Cd}^{2+}$ may substitute $\mathrm{Ca}^{2+}$ in the crystal lattice of $\mathrm{CaCO}_{3}$, according to their similarity in ionic radius ${ }^{[32]}$. 
Am. J. Environ. Sci., 2 (2): 49-59, 2006

Table 4: Concentration factor for some ions in sea grass and algae species collected from the coastal water of Mediterranean Sea during

\begin{tabular}{|c|c|c|c|c|c|}
\hline Species & Sector & $\mathrm{Ca}$ & $\mathrm{Mg}$ & $\mathrm{SO}_{4}$ & $\mathrm{~F}$ \\
\hline Sea grass & El Alamein (2000) & 78.04 & 16.88 & 23.2 & 9129.7 \\
\hline \multirow[t]{2}{*}{ Posidonia Oceanica } & Abu Qir (2001) & 94.05 & 4.65 & 174.5 & 6634.7 \\
\hline & El Alamein (2001) & 199.74 & 31.11 & 169.6 & 6081.6 \\
\hline Green Algae & El Alamein (2001) & 371.70 & 5.39 & 21.9 & 12935.1 \\
\hline \multirow[t]{4}{*}{ Penicillus capitatus } & Abu Qir (2001) & $1018 . .9$ & 18.50 & 147.6 & 4269.5 \\
\hline & Ras El Hikmah (2001) & 1301.9 & 6.12 & 113.8 & 6340.2 \\
\hline & Marsa Matruh (2001) & 1562.1 & 4.59 & 47.4 & 6851.8 \\
\hline & Sidi Barrani (2001) & 1317.2 & 16.21 & 139.4 & 5297.0 \\
\hline \multirow[t]{5}{*}{ Codium bursa } & Abu Qir (2001) & 504.5 & 20.18 & 252.7 & 5614.7 \\
\hline & El Alamein (2001) & 256.1 & 23.36 & 189.0 & 4765.9 \\
\hline & Ras El Hikmah (2001) & 352.3 & 20.41 & 274.3 & 8951.4 \\
\hline & Marsa Matruh (2001) & 444.7 & 22.75 & 177.3 & 8843.7 \\
\hline & Sidi Barrani (2001) & 978.4 & 1.80 & 161.2 & 4903.3 \\
\hline Ulva lactuca & Sidi Barrani (2001) & 370.63 & 20.26 & 791.9 & 4065.0 \\
\hline Red Algae: & El Alamein (2000) & 453.5 & 4.23 & 13.7 & 7221.6 \\
\hline \multirow[t]{4}{*}{ Amphiroa sp. } & Abu Qir (2001) & 1308.6 & 4.64 & 104.1 & 5614.7 \\
\hline & El Alamein (2001) & 1608.1 & 14.68 & 62.1 & 5023.1 \\
\hline & Ras El Hikmah (2001) & 1605.2 & 20.41 & 164.9 & 7780.1 \\
\hline & Sidi Barrani (2001) & 1319.2 & 5.48 & 70.4 & 5785.6 \\
\hline Brown Algae: & Ras El Hikmah (2001) & 420.9 & 6.12 & 307.8 & 7780.1 \\
\hline \multirow[t]{2}{*}{ Sargassum $s p$} & Marsa Matruh (2001) & 553.2 & 15.44 & 226.3 & 5897.6 \\
\hline & Sidi Barrani (2001) & 392.3 & 23.71 & 146.8 & 4724.1 \\
\hline
\end{tabular}

So, each algal species seems to have certain chemical composition. Some algae appear to uptake certain elements rather than others, according to many factors such as: ambient environment, the availability of metals to be accumulated, physiological variations among species ${ }^{[33]}$, growth stages, time of collection, temperature, ..etc ${ }^{[16]}$.

Cadmium content in the muscle is ranged from 0.005 to $0.016 \mu \mathrm{g} \mathrm{g}^{-1}$, Fig. 3. The relative high content in the fish samples reflects its existence in seawater, feeding and sediment ${ }^{[27]}$. The cadmium concentration in the muscle of Mugil seheli and Tilapia aurata was fluctuated between $0.33 \pm 0.01$ and $0.22 \pm 0.03 \mu \mathrm{g} \mathrm{g}^{-1}$ wet wt along Suez Canal, respectively ${ }^{[27]}$. It was recorded that ${ }^{[27]}$ its content in the muscle of Boops boops gathered from Mediterranean Sea was ranged between $0.92 \pm 0.66$ and $1.38 \pm 0.13 \mu \mathrm{g} \mathrm{g}^{-1}$, respectively ${ }^{[27]}$. It was reported that the cadmium content in the flesh of varies marine fish gathered from the Arabian Sea was $0.35 \pm 0.09,0.36 \pm 0.10$ and 0.26 $\pm 0.03 \mu \mathrm{g} \mathrm{g}^{-1}$ wet wt for Chactadon jayakeri, Rastrelliger kanugurta and Pomadysis maculatum, respectively ${ }^{[29]}$. The present study revealed lower levels of cadmium particularly in the different fish species compared with those of Health Standard Levels $(0.5 \mathrm{mg}$ $\mathrm{Kg}^{-1}$ ), established by U.S. National Academy of Science. The recommendation of National Health and Medical Research Council in Australia (NHMRC), stated that the concentrations of cadmium and lead in edible parts of fish should not exceed $2.0 \mathrm{mg} \mathrm{Kg}^{-1}$.
In contrast to NHMRC levels, the Western Australian Food and Drug Regulations gave concentrations of 5.5 and $40 \mathrm{mg} \mathrm{Kg}^{-1}$ for $\mathrm{Cd}$ and $\mathrm{Zn}$, respectively ${ }^{[29]}$. Generally, the present data demonstrate that there is no risk for the human consumption of the fish samples collected from the Egyptian coast of Mediterranean Sea.

The order of the determined constituents in algal species is as follows:

Sea grass: $\quad \mathrm{SO}_{4}>\mathrm{Ca}>\mathrm{F}>\mathrm{Mg}>\mathrm{P}>\mathrm{Fe}>\mathrm{Zn}>\mathrm{Mn}>$ $\mathrm{Cu}>\mathrm{Ni}>\mathrm{Co}>\mathrm{Cd}$

Green algae: $\mathrm{Ca}>\mathrm{SO}_{4}>\mathrm{F}>\mathrm{Mg}>\mathrm{P}>\mathrm{Fe}>\mathrm{Zn}>\mathrm{Ni} \geq$ $\mathrm{Mn}>\mathrm{Co}>\mathrm{Cu}>\mathrm{Cd}$

Red algae: $\quad \mathrm{Ca}>\mathrm{SO}_{4}>\mathrm{F}>\mathrm{Mg}>\mathrm{P}>\mathrm{Fe}>\mathrm{Ni}>\mathrm{Co}>$ $\mathrm{Zn}>\mathrm{Mn}>\mathrm{Cu}>\mathrm{Cd}$

Brown algae: $\mathrm{SO}_{4}>\mathrm{Ca}>\mathrm{F}>\mathrm{Mg}>\mathrm{P}>\mathrm{Fe}>\mathrm{Zn}>\mathrm{Mn}>$ $\mathrm{Ni}>\mathrm{Cu}>\mathrm{Co}>\mathrm{Cd}$

Sea grass $\quad \mathrm{Ca}>\mathrm{SO}_{4}>\mathrm{F}>\mathrm{Mg}>\mathrm{P}>\mathrm{Fe}>\mathrm{Zn}>\mathrm{Mn}>$ $\mathrm{Ni}>\mathrm{Co}>\mathrm{Cu}>\mathrm{Cd}$

and algae:

It seems that both Posidonia oceanica (macrophyte) and brown algae contain high sulphate content, while green and red algae show maximum calcium concentration.

The order of the parameters contents in the collected fish species is given as follows: $\mathrm{SO}_{4}>\mathrm{Mg}>\mathrm{Ca}>\mathrm{P}>\mathrm{F}>\mathrm{Fe}>\mathrm{Co}>\mathrm{Zn}>\mathrm{Ni}>\mathrm{Mn} \geq \mathrm{Cu}>\mathrm{Cd}$.

It was stated that ${ }^{[16]}$ the heavy metal contents in the muscle of fish samples collected from Red Sea were in order : $\mathrm{Fe}>\mathrm{Zn}>\mathrm{Mn}>\mathrm{Pb}>\mathrm{Cu}>\mathrm{Ni}>\mathrm{Cr}>\mathrm{Co}>\mathrm{Cd}$. 


\section{Statistical analysis:}

a) Correlation matrix: The correlation matrices for all the parameters ( $\mathrm{Ca}, \mathrm{Mg}, \mathrm{SO}_{4}, \mathrm{P}, \mathrm{F}, \mathrm{Cd}, \mathrm{Mn}, \mathrm{Fe}, \mathrm{Co}, \mathrm{Ni}$, $\mathrm{Cu}$ and $\mathrm{Zn}$ ), indicate that:

Algae: $(\mathrm{n}=25, \mathrm{p}<0.05)$ : High significant negative correlations for calcium among magnesium $(\mathrm{r}=-0.4937$, $\mathrm{p}<0.012)$, sulphate $(\mathrm{r}=-0.4622, \mathrm{p}<0.020)$ and manganese contents $(r=-0.4604, p<0.021)$, respectively, are probably attributed to the inhibition of $\mathrm{CaCO}_{3}$ formation by magnesium ions. However, magnesium can substitute for calcium in calcite ${ }^{[28]}$. It seems that the decrease in sulphur and manganese contents is accompanied with large calcium existence in the algal species.

High positive significant correlations for calcium among cadmium $(\mathrm{r}=0.8929, \mathrm{p}<0.000)$, cobalt $(\mathrm{r}=0.9792$, $\mathrm{p}<0.000)$ and nickel $(\mathrm{r}=0.9420, \mathrm{p}<0.000)$, may reflect the substitution of calcium ion by both cadmium and nickel into the crystal lattice of $\mathrm{CaCO}_{3}$ minerals ${ }^{[32]}$. The increase in calcium content probably increase the formation of compounds containing cobalt ${ }^{[10]}$.

The high positive significant relations for cadmium among both cobalt $(\mathrm{r}=0.9304, \mathrm{p}<0.000)$ and nickel $(\mathrm{r}=0.9155, \mathrm{p}<0.000)$ contents, possibly show the great effect of cadmium on the formation of both elements in algal species ${ }^{[10]}$.

A positive correlation between manganese and copper $(\mathrm{r}=0.6096, \mathrm{p}<0.001)$, indicating that the accumulation of copper content leads to the stimulation in both photosynthesis and growth of the algal species $^{[10]}$.

A positive high significant relation between cobalt and nickel contents $(\mathrm{r}=0.9632, \mathrm{p}<0.000)$, may show that the stimulation of cobalt components is accompanied with the increase in nickel content ${ }^{[10]}$.

Zinc and copper contents show a high significant positive correlation $(\mathrm{r}=0.8228, \mathrm{p}<0.000)$, where, $\mathrm{Cu}^{2+}$ may substitute $\mathrm{Zn}^{2+}$ in the growth mechanisms of the algal species ${ }^{[32]}$.

Fish: (n=8): The correlation matrix for $\mathrm{Ca}, \mathrm{Mg}, \mathrm{SO}_{4}, \mathrm{P}$, $\mathrm{F}$ and length values indicates a positive significant relation between calcium and phosphorus contents in the muscle of the fish samples $(\mathrm{r}=0.7512, \mathrm{p}<0.032)$. However, the inhibition of phosphate metabolism is accompanied with a decrease in the intestinal absorption of calcium ${ }^{[34]}$.

The correlation matrix for $\mathrm{F}$ and the studied heavy metal contents shows a positive significant relation between $\mathrm{Mn}$ and $\mathrm{Zn}(\mathrm{r}=0.8452, \mathrm{p}<0.008)$. However, manganese or zinc binds the acceptor substrate to the enzyme during the carboxylate transfer ${ }^{[34]}$. A negative significant correlation between $\mathrm{Ni}$ and $\mathrm{Cd}(\mathrm{r}=-0.8957$, $\mathrm{p}<0.003$ ) is assigned reflecting that the decrease in the nickel content is accompanied with an increase in cadmium accumulation.

\section{b) Stepwise regression analysis:}

1)Algae: $(n=25)$

$\mathrm{F}=33.08-0.26 \mathrm{Cu}$

$\mathrm{R}=0.263422, \mathrm{R}^{2}=0.069391, \mathrm{p}<0.2033$

$\mathrm{Cd}=-0.003+1.40 \mathrm{Co}+0.22 \mathrm{~F}+0.08 \mathrm{Cu}-0.42 \mathrm{Ca}+0.09 \mathrm{SO}_{4}$ $\mathrm{R}=0.959857, \mathrm{R}^{2}=0.921326, \mathrm{p}<0.0000$

$\mathrm{Co}=0.55 \mathrm{Ca}+0.22 \mathrm{Cd}+0.24 \mathrm{Ni}-0.06 \mathrm{SO}_{4}-0.04 \mathrm{~F}+0.04 \mathrm{Mg}$

$\mathrm{R}=0.992246, \mathrm{R}^{2}=0.984552, \mathrm{p}<0.0000$

$\mathrm{Cu}=0.01+0.68 \mathrm{Zn}+0.32 \mathrm{Mn}+0.19 \mathrm{P}-0.12 \mathrm{~F}$

$\mathrm{R}=0.916399, \mathrm{R}^{2}=0.839787, \mathrm{p}<0.0000$

All these equations lead to conclude that algal calcification process is affected by the chemical composition of sediment and water column in each sector. Protein, chlorophyll and cobalt components contents are probably accompanied with the specific uptake of each species, ambient environment, availability of the uptake of elements from sediment, temperature, time of collection, ..etc. Cadmium plays an important role in many physiological processes and substitutes $\mathrm{Ca}^{2+}$ in the crystal lattice of $\mathrm{CaCO}_{3}$ formation. Furthermore, $\mathrm{Cu}^{2+}$ can substitute also for $\mathrm{Zn}^{2+}$ in essential growth mechanisms ${ }^{[29]}$. Significant correlations indicate that cadmium content may affect the formation of protein and cobalt components, growth mechanisms and photosynthesis processes.

Fluoride shows high accumulation in both seaweeds and sea grass. Although, the correlation matrix analysis doesn't give any significant relation between fluoride and any determined parameters contents at $\mathrm{p}<0.05$, stepwise regression leads to a weak relation between it and copper, [equation (2)]. Also, fluoride shows significant relations among $\mathrm{Cd}$, Co and $\mathrm{Cu}$ contents, equations ( 3,5 and 7$)$, reflecting its effect on the physiological processes in both marine machrophytes and algal species ${ }^{[3]}$. This conclusion may indicate the probability of the transportation of this ion to fish, molluscs, crustaceans, echinoderms and other aquatic species by feeding process. However, algae form the base of many aquatic food chains ${ }^{[10]}$.

Fish: $(\mathbf{n}=\mathbf{8})$ :

* When using this analysis for fluoride as a dependent parameter and the others as independent ones $\left(\mathrm{Ca}, \mathrm{Mg}, \mathrm{SO}_{4}\right.$ and length), an insignificant relation is obtained. The result indicates that fluoride content in the muscle of the fish is not affected by the value of previous parameters.

* The stepwise regression analysis for $\mathrm{F}$ and heavy metal contents ( $\mathrm{Fe}, \mathrm{Mn}, \mathrm{Co}, \mathrm{Ni}, \mathrm{Zn}, \mathrm{Cu}$ and $\mathrm{Cd}$ ) are shown in these equations:

$\mathrm{Co}=0.23+0.31 \mathrm{~F}-0.92 \mathrm{Cu}-1.2 \mathrm{Mn}+0.72 \mathrm{Zn}$

$\mathrm{R}=0.956127 . \mathrm{R}^{2}=0.914180, \mathrm{p}<0.0596$

$\mathrm{Ni}=0.17-0.19 \mathrm{~F}-0.89 \mathrm{Cd}$

$\mathrm{R}=0.915935, \mathrm{R}^{2}=0.838937, \mathrm{p}<0.0104$

The stepwise regression and correlation matrix analyses, indicate that fluoride content in the muscle of fish samples is not accompanied with either the major components $\left(\mathrm{Ca}, \mathrm{Mg}, \mathrm{SO}_{4}\right.$ and $\left.\mathrm{P}\right)$ or the minors concentrations (heavy metal). Equations 1 and 2, show 
that fluoride plays as an important role in metabolism, growth, reproduction and other biological processes ${ }^{[3]}$. However, $\mathrm{Co}$ and $\mathrm{Ni}$ are essential elements for the physiological mechanisms in marine organisms ${ }^{[35]}$.

\section{REFERENCES}

1. Hall, R.J., 1968. Observations on the distribution and determination of fluorine compounds in biological minerals, including soils. Analyst, 93: 461.

2. Oliveira, L., 1978. Culture studies on the effects from fluoride pollution on the growth of marine phytoplankters. J. Fish. Res. Board Can., 35: 1500.

3. Moore, D.J., 1971. The uptake and concentration of fluoride by crab, Callinectes spades. Chesapeake Sci., 12: 1.

4. Liteplo. R., R. Gomes, P. Howe and H. Malcom, 2002. Environmental health criteria 227. World Health Organization, Genva, pp: 290.

5. Culik, B., 1987. Fluoride turnover in adelie penguins (Pygoscelis adeliae) and other bird species. Polar Biol., 7: 179.

6. APHA-AWWA-WPCF, 1975. Standard methods for the examination of water and waste water, $14^{\text {th }}$ edition, American Public Health Association, Washington, D.C.20036, USA, pp: 1193.

7. Courtenary, D.A. and J.R. Rex, 1951. The spectrophotometric determination of fluoride in seawater. J. Marine Res., 12: 203.

8. Strickland, J.D.H. and T.R. Parson, 1965. A manual of Seawater Analysis. 2nd Ed. Issued by Fisheries Research Board of Canada, pp: 203.

9. Clark, G.M. and D. Cook, 1992. A basic Course In Statistics. 3rd Edn. Edwarld Arnold Educational Low-Priced Books Scheme Funded by British Government, pp: 45.

10. Stewart, W.D.P., 1974. Botanical Monographs, Algal physiology and Biochemistry, Black Well Scientific Publications Ltd Osney Mead, Oxford, 10: 989.

11. El Sarraf, W.M., 1995. Chemical analysis of some macrophytes in Mariut and Edku Lakes, Egypt. Alex. J. Agricul. Res., 40: 255.

12. Baudo, R., G. Gatanti, P. Guilizzoni and P.G. Varini, 1981. Relationships between heavy metals and aquatic organisms in Lake Mezzola hydrographic system (Northern Italy), 4, Metal concentrations in six submersed aquatic macrophytes. Memorie dell stituto Iraliano di Idrobiogia, 39: 203.

13. Youssef, D.H., 1993. Studies on some inorganic chemical constituents of marine algae in relation to their environments. M.Sc. Thesis, Chemistry Department, El-Mansoura University.

14. Milliman, J.D., 1974. Marine Carbonates. Springer Verlage Berlin. Heidelberg, New York, pp: 375.
15. Shackley, P.E., C. Talbot and A. Cowan, 1993. The use of whole-body sodium, potassium and calcium content identify the nutrient status of first year salmon fry. J. Fish Biol., 43: 825.

16. Mohamed, H.A.E., 2002. Heavy metals in Suez Canal relevant to the impacts of land based sources. Ph.D Thesis. University of Mansoura, Faculty of Science, Department of Chemistry, pp: 223.

17. Wurts, W.A. and R.M. Durborow, 1992. Interactions of $\mathrm{pH}$, carbon dioxide, alkalinity and hardness in fish ponds. Southern Regional Aquacul. Cent., Dec., 464: 1.

18. Whitehead, P.J.P., M.L. Bauchot, J.C. Hureau, J. Nielsen and E. Tortonese, 1986. Fishers of the north eastern Atlantic and Mediterranean, United Nation Educational, Scientific and Cultural organization (UNESCO), pp: 1473.

19. Tanner, D.K., J.C. Brazner and V.J. Brady, 2000. Factors influencing carbon, nitrogen and phosphorus content of fish from a Lake Superior coastal wetland. Can. J. Fish. Aquat. Sci., 57: 1243.

20. Antia, N.J., 1976. Effects of temperature on the darkness survival of marine microplanktonic algae. Microbial Ecol., 3: 41.

21. Grave, H., 1981. Fluoride content of salmonids fed on antarctic krill. Aquaculture, 24: 191.

22. Adeung, D., F. Buchholz, B. Culik and A. Keck, 1987. Fluoride in tissues of Krill Euphausia superba Dana and Meganyctiphanes norvegica $\mathrm{M}$. Sars in relation to the moult cycle. Polar Biol., 7: 43.

23. Foulkes, R.G., 1995. Inorganic fluorides, Canadian environmental protection act (priority substances list assessment report, government of Canada 1993). Fluoride, 28: 129.

24. St-Cyr, L. and P.G.C. Campbell, 2000. Bioavailability of sediment-bound metals for Vallisneria americana Michx, a submerged aquatic plant, in the St. Lawrence River. Can. J. Fish. Aquat. Sci., 57: 1330.

25. El Deeb, M.K. and W.M. Aboul-Naga, 2002. Trace metals: $\mathrm{Fe}, \mathrm{Zn}, \mathrm{Mn}, \mathrm{Cu}, \mathrm{Ni}$ and $\mathrm{Cr}$ in macroalgae from Alexandria coast; Bull. Fac. Sci., Alex. Univ., 42: 51.

26. Jackson, L.J., J. Kalff and J.B. Rasmussen, 1993. Sediment $\mathrm{pH}$ and redox potential affect the bioavailability of $\mathrm{Al}, \mathrm{Cu}, \mathrm{Fe}, \mathrm{Mn}$ and $\mathrm{Zn}$ to rooted aquatic macrophytes. Can. J. Fish. Aquqat. Sci., 50: 143 .

27. Mahmoud, Th.H. and S.M. Allam, 2002. Heavy metals, protein and lipid concentrations in the muscle, liver and gonads of Boops boops. J. Egypt. Ger. Soc. Zool., 37(A): 225.

28. Degens, E.T., 1976. Molecular mechanisms on carbonate, phosphate and silica deposition in the living cell, Springer-Verlage, Berlin Heidelberg, New York, pp: 110. 
29. Tariq, J., M. Jaffar, M. Ashraf and M. Moazzam, 1993. Heavy metal concentrations in fish shrimp, seaweed, sediment and water from the Arabian Sea, Pakistan. Mar. Poll. Bull., 26: 644.

30. Aboul Naga, W.M. and S.M. Allam, 1996. Heavy metal concentrations in the tissues of Tillapia zillii gerv, exposed to waste water discharge of Egyptian copper factory. J. Egypt. Ger. Soc. Zool., 19(A): 21.

31. Lozano, G., A. Hardisson, A.J. Gutierez and M.A. Lafuente, 2003. Lead and cadmium levels in coastal benthic algae (seaweeds) of Tenerife, Canary Island. Environ. Intl., 28: 627.

32. Macalady, D.L., 1998. Perspectives in Environmental Chemistry. New York, Oxford, Oxford University Press, pp: 512.
33. Lozano, G., Lead and cadmium levels in coastal benthic algae (seaweeds) of Tenerife, Canary Island; Environ. Int., 28: 627.

34. Frederick, S., S. Russell and S.M. Yonge, 1972. Advances in Marine Biology. Academic Press. London and New York, 10: 555.

35. McGilver, R.W. Ph.D., W.B. Concepts, 1975. Saunders Company, Philadelphia, London, Toronto, pp: 530.

36. Whitehead, P.J.P., M.L. Bauchot, J.C. Hureau, J. Nielsen and E. Tortonese, 1986. Fishers of the north eastern Atlantic and Mediterranean. United Nation Educational, Scientific and Cultural organization (UNESCO), pp: 1473. 